\title{
The Initial Success of The Chagas' Disease Control Program: Factors Contributing to Triatomine Infestation
}

\section{O Sucesso Inicial do Programa de Controle da Doença de Chagas: Fatores Associados com a Infestação por Triatomíneos}

\author{
Millicent Fleming-Moran ${ }^{1}$
}

FLEMING-MORAN, M. The Initial Success of The Chagas' Disease Control Program: Factors Contributing to Triatomine Infestation. Cad. Saude Públ., Rio de Janeiro, 8 (4): 391-403, oct/dec, 1992.

While the control of the major Chagas' disease vector Triatoma infestans has been achieved in many endemic areas of Brazil, data from the inception of the control program in the Triângulo Mineiro (1976-79) suggest that re-infestation by triatomines occurs under certain favorable conditions. The percentage of houses infested in 500 communities of the Triângulo Mineiro region is compared for two years: 1976 and 1979, using linear regression models. Controlling for three major triatomine vectors, household crowding, house demolition and construction, and infested out-buildings are all independent covariates of house infestation in these communities. While several household factors have been suggested as correlates of infestation, the control program focuses on community-level reductions in infestation, but intra-community or regional comparisons have heretofore been unfeasible. Computerized data are becoming available to identify communities at high risk for re-infestation, and for targeting control-program activities. Keywords: Chagas' Disease; Control; Triatoma sp.; Brasil

\section{INTRODUCTION}

Chagas' disease is a parasitic disease caused by Trypanosoma cruzi, carried to humans by Triatoma (family Reduviidae) insects. It is endemic throughout Southem and Central America, affecting 16-17 million persons (Maurice \& Pierce, 1987), or 8\% of the Latin American population (Schofield, 1985). In Brazil the disease is estimated to account for $10 \%$ of deaths among adults aged 25 to 65 (Maurice \& Pierce, 1987; Pereira, 1984). Ten percent of cases die in the acute phase; $40 \%$ will suffer chronic symptoms in prevalent cases (Schofield, 1985).

Long-term infection can lead to chronic myocarditis, congestive heart failure, cardiac arthythmias, and even sudden death in approximately $20 \%$ of cases, often decades

\footnotetext{
${ }^{\prime}$ Regenstrief Center for Health Care Research. 1001 Tenth Street, Indianapolis IN, USA.
}

after initial infection. The disease, following an acute often asymptomatic phase of 1-2 months currently has no cure, and infection is life-long (Kirchhoff et al., 1987). Infection can be transmitted congenitally, and via blood transfusion (Grant et al., 1989). The latter is now the greatest threat in countries like Brazil (Dias et al., 1985; Kirchhoff et al., 1987; Grant et al., 1989).

The major public health measure available is to reduce the contact between humans and $T$. cruzi-bearing vectors through regular inspection of housing and application of insecticides. During 1975-77, Brazil undertook a massive national study of Chagas' disease prevalence and distribution. Simultaneously, the Ministry of Health (MS/Sucam) began to spray dwellings in high prevalence regions to control triatomine vectors. As of 1987, the program annually expended between $35-40$ million U.S. dollars to reach sóme 2445 counties (MS/Sucam/World Bank, 1987). 


\section{OBJECTIVES OF THE STUDY}

This research examines data gathered by the control program in its early period, which may be useful in re-focusing spraying efforts in the future. Data were available for the Triângulo Mineiro region of the state of Minas Gerais, as a continuous record of the control program from 1976 to 1979 for all 500 localities sampled in the Region's 60 counties during the National Prevalence Survey (Camargo et al., 1984). While a few longitudinal studies have been undertaken in small rural communities, there has never been regional-level assessment of factors explaining variation in triatomine distribution and level of household infestation. Moreover, The Triangulo region, which borders the states of São Paulo, and Goiás, is a confluence region for three major insect vectors of the disease; Triatoma infestans, Triatoma sordida, and Panstrongylus megistus. This area has exhibited communities with some of the highest prevalence of Chagas' disease (Camargo et al., 1984).

Household crowding is a primary limiting factor on the carrying-capacity for household triatomine population (Schofield, 1980; Marsden et al., 1982; Piesman et al., 1983). However, early research findings are based on a few houses in a few small communities. Triatomines go through five stages before reaching adulthood, each requiring a blood meal for development. Positive associations between human crowding and both householdlevel prevalence (Mott et al., 1978) and incidence of the disease (Marsden et al., 1982; Piesman et al., 1983; Hoff et al., 1985), and with vector density has also been noted. Household crowding has not been examined for community infestation level, nor for its relevance to long-term control of infestation.

Community-level studies of the disease also indicate great loss of local rural population during relatively short study periods, in some cases as much as $10-12 \%$ per year (Marsden et al., 1982; Mota et al., 1990). This is most likely for persons involved in the migrant labor force (adolescents to about age 40, an age group which exhibits the highest prevalence of Chagas' infection) (Mota et al.,
1990). Questions are frequently raised concerning migration effects on Chagas' and other endemic diseases in Brazil's expanding rural frontiers (Foratinni et al., 1971; Litvoc, 1979; Marques \& Pinheiro, 1979; Marques, 1982; Haddock, 1979; Hoff et al., 1985; Bentham, 1988), as well as its growing urban areas (Pereira, 1984).

While migration cannot be studied directly using the control program's data, change in a local population can be assessed indirectly in two ways. First, the National Prevalence Survey asked whether the individuals residing in sampled households had been born in the locality or elsewhere. This allows a rough estimation of the proportion of a locality's 1976 adult population who were long-term residents.

Secondly, the control program's semestral housing census kept track of demolition of older housing, and replacement by newer housing. Regular housing change has also been noted in the literature, but has not been used in evaluating local-level success of the control program (Marsden et al., 1982; Mota et al., 1990). These particular aspects would have direct impact on household infestation as the length of time a dwelling is inhabited, and deteriorated condition are good predictors of its infestation level (Mott et al., 1978). Many researchers note the relationship between the poor quality of rural housing and high rates of prevalence of the disease and triatomine infestation (Zeledon \& Rabinovich, 1981; De Raat, 1976; Marsden, 1981; Dias \& Dias, 1982; Dias, 1985), whereas residential hygiene (Piesman et al., 1983) and general measures of individual wealth (Marsden et al., 1982) do not always show a direct relationship. It has been proposed that removal of older housing could reduce infestation if newer housing is of better quality (Julien-Laferrier et al., 1989), and is well maintained (Schofield \& Marsden, 1982). Demolition of infested housing, however, might equally increase local-level infestation rate if these houses are not replaced. Shifts in the rates of new construction and demolished housing have never been explored in their relation to local household infestation in the literature. 
This research explores 1) the role of household crowding, and 2) the independent contributions of construction and demolition of housing, in local rates of dwelling infestation at the beginning of the spray program in 1976 in 500 selected communities of the Triangulo Mineiro region. Then these factors are re-examined, once the program was in effect, for the same communities in 1979.

\section{METHODS}

During the mid-1970's, the Ministry of Health's Statistical Division devised a proportional sampling plan of enumerated localities throughout Brazil. Each locality was mapped, and baseline population counted during the control program's "geographic reconnaissance" phase, using a unique house enumeration system. Each state's sample for the prevalence survey was weighted to oversample small rural clusters of houses, especially aggregates smaller than 200 houses (Camargo et al., 1984).

The Triangulo region was one of the exceptional regions where the prevalence and geographic surveys coincided with the initiation of the spray program. Data have been merged for the 445 of the 500 total localities which meet this criteria, to include baseline disease prevalence, demographic, and house infestation information for the baseline year of the spray program in the area (1976). The model developed for initial locality infestation is then compared to that for 1979 , wherein each locality had been inspected and sprayed for at least two years, and where data on community populations are still recorded.

\section{Definition of Variables}

The dependent variable used in these regression analyses is the percentage of a locality's inspected houses infested by triatomine insects. A small percentage difference may exist between the inspected versus total existing houses, where inspection teams may not have entered temporarily vacated houses, or others which were permanently boarded and closed (on average less than $10 \%$ of all houses). As infested annexes or outbuildings provide a residual vector population to re-infest dwellings, the ratio of infested annexes to total dwellings is also tested as a variable.

The community population totals were updated each semester the spray program visited until 1979, when enumeration of inhabitants ceased. A community-level indicator of crowding is estimated by dividing the number of total residents, by the number of inhabited houses per locality in each visitation period. In addition, the 1976 National Prevalence Survey asked residents from a strict protocol of pre-selected sampled households whether they had been born in their current location. Thus, the adult immigrant-to-locally born ratio provides an approximation of population influx in each locality. High and low migration locations are defined as those whose adult population over age 15 include more or less than $50 \%$ of immigrants, respectively.

Three other indicators of recent populational change in the community include: the total number of houses built or demolished in the previous semester, and the net total of existing houses in each visitation. In the baseline year (1976), these figures represent the houses torn down or newly constructed in the six months prior to the advent of the spray program. The rate of demolition is defined as the ratio of houses demolished in the the interim between visits, to those remaining in the current period. The rate of new construction is similarly defined each semester.

A rural-urban dichotomous variable uses locational categories from Sucam records and contrasts small and medium sized farms with villages, small towns and cities. This roughly coincides with clusters of over or under 250 houses. The proximity of a stream or low-land area is also indicated by a designation of the locality as one which is sprayed by the antimalaria control program. Malarial areas also included some of the poorer housing in the region according to local Chagas' program officials.

All tested models for the level of dwelling infestation control for the presence of each of 
the three major triatomine vectors in a community, as well as the existence of more than one vector species in any period of time. The additional explanatory power of all other variables will be tested after these four are forced into a linear regression model. A weighted ordinary least-squared regression model is developed for each period (1976; 1979), using SAS regression modeling package programs. A backwards and forwards variable selection process evaluates the independent contribution of each variable, and of two-variable interaction terms when others are already entered in the model. Inclusion is tested by means of the partial $F$ test at a .05 level of significance. The first recorded visit per locality is used for each of the two years of study.

\section{RESULTS}

The 1976 house infestation model: The overall rate for house (not including annex) infestation for the Triangulo region's sampled localities was $6.6 \%$ of all inspected houses in 1976. However, this ranges between 113 communities with no house infestation to some with over $60.0 \%$ of their houses infested. In developing the baseline 1976 model however, it became apparent that separate models were required due to significant interaction effects between predominant vector species, rates of house demolition and the proportion of immigrant adults, in areas which were or were not previously covered by the malaria control program.

In Table 1, initial 1976 house infestation in the 227 localities in anti-malaria program areas was most influenced by the vector $T$. infestans (which brings the ratio of infested/ total inspected houses to $16.7 \%$ ). After T.infestans, $T$. sordida independently raises the infestation ratio another $10.5 \%$, and $P$. megistus adds $5.9 \%$, once the other two vectors were considered. More than one house vector per locality contributed a further $5.0 \%$, as did the demolition of houses prior to the advent of the spraying program (for an additional $3.9 \%$ ).

In contrast, $T$. infestans contributed to a lesser degree to house infestation in the 270 non-malaria program areas, infesting $11 \%$ of all inspected houses. Here $P$. megistus and T.sordida contributed equally (each over $7.0 \%$ ), and multiple vectors' magnitude of effect was similar to that seen in malariaprogram localities (3.8\%).

TABLE 1. Regression Models for Household Triatomine Infestation by Localities Wich Where or Were Not Sprayed for Malaria Control; Triangulo Mineiro, 1976

\begin{tabular}{lrrrr}
\hline \hline Malaria-Spray Program Areas (N=227 localities, R-square=.28) & s.e. & T & $\mathrm{p}^{<}$ \\
\hline Intercept &. .005 & .017 & & \\
Presence of: & .167 & .023 & 7.26 & .0001 \\
$T$. infestans & .105 & .021 & 4.80 & .001 \\
$T$. sordida & .059 & .027 & 2.16 & .03 \\
$P$. megistus & & & & \\
\% Houses Demolished & .039 & .014 & 2.73 & .006 \\
Multiple vector species & .050 & .019 & 2.75 & .006 \\
\hline Non-Malarial Areas (n=270 localities, R-square=.28) & & & & \\
\hline Intercept & .0002 & .002 & & \\
Presence of: & .113 & .021 & 5.43 & .0001 \\
$T$. infestans & .071 & .016 & 4.35 & .0001 \\
$T$. sordida & .074 & .013 & 5.50 & .0001 \\
$P$. megistus & & & & \\
Multiple vector species & .038 & .016 & 2.32 & .02 \\
Infested outbuilding/house ratio & .13 & .06 & 2.19 & .029 \\
\hline \hline
\end{tabular}


A high immigrant-to-locally born adult ratio, e.g. where over $50.0 \%$ of a locality's adults are not locally born, approached significance in non-malarial areas, but neither the immigration ratio nor house demolition ratio were retained, once prevalent insect vectors were forced into the model. Above all, house infestation in non-malaria areas is most affected by the ratio of infested outbuildings to households. This variable independently contributes $13 \%$ to the overall infestation level, a role nearly equal to that of $T$. infestans, even when the direct role of all vectors has been accounted for in the model.

The two regression models for malarial and non-malarial localities accounted for some 26.0-28.0\% of the variance in house infestation levels in these respective areas. The average number of persons per household failed to enter either stratas' 1976 infestation model, once the three vectors and multiple vectors were included in the models. Univariate data corroborate the fact that the average household size varied little by malarial/non-malarial area or by rural-urban location, in 1976.

Few localities saw significant new construction of housing in 1976; most declined in total number of houses, particularly in rural areas. However, net growth of newer housing i.e. with a net increase of $15.0 \%$ or more was marginally associated with lower rates of house infestation in univariate analyses.

The 1979 post-control program model:

By 1979, the Chagas' control program reached all locations in the sample. However, data on the quantity or types of spray used per locality are not entered as independent variables in the second panel year model because: 1) there was a fixed formula for mixing BHC insecticide solution, and a standard protocol for spraying house interiors, which was followed by all teams in the region (Silveira, 1985); 2) Only a handful of localities were ever missed in their semestral spray cycle between 1976 and 1979 in this region; and 3) all infested houses and their environs per locality were sprayed in these early years (Marsden, 1981; Silveira, 1985). Thus, use of spraying activity variables results in severe problems of multi-collinearity and failure to interpret the models for 1979 .

By 1979, 214 localities, or $48 \%$ were reportedly free of house infestation, up from 133 localities in 1976. House-infestation free locations are included in the 1979 model as they were in the 1976 model. In univariate analyses there are no significant differences in house-infestation free locations' average household size, nor their demolition rates in comparison to localities which remained house-infested. All had at least two full years of spraying. Those free of house infestation were likely to experience greater rates of new housing construction. This reflects the influence of certain urban locations which far surpassed many rural areas net growth of housing and population.

$T$. infestans appeared in 14 localities (6.1\%), T. sordida in $111(48.1 \%)$, and P.megistus in 97 in 1979 (41.1\%). The regional prevalence of house infestation drops from $6.6 \%$ of all inspected houses in 1976 to $2.5 \%$ of houses in 1979 (Table 2), a testimony to the early effectiveness of household spraying. In a model for 1979 house infestation, the role of $T$. infestans drops to roughly half the level seen four years earlier (accounting for $6.0 \%$ of all houses being infested). $P$. megistus replaces $T$. sordida as the second most prevalent houseinfesting vector, adding a further $4.0 \%$ to infestation levels. $T$. sordida and multiple vectors, however, are not significant covariates in the overall house infestation model by 1979 , but still play an important role in annex infestation.

While the rate of house demolition declined from a high annual rate of $11.3 \%$ (or roughly one out of ten existing houses) in 1976, to $5.7 \%$ by 1979 , demolition still acts to increase house infestation rates in this period. In 1979, the ratio of infested outbuildings/houses also positively influences house infestation, as it did originally in the 1976 model for nonmalarial localities. For the first time, however, the ratio of new-to-existing houses is positively associated with house infestation levels. This is in contrast to 1976 univariate data, which, though not statistically significant, suggested an inverse relationship 
TABLE 2. Household Triatomine Infestation Levels: Triangulo Mineiro Region, 1976-79

\begin{tabular}{lrrrr}
\hline \hline & 1976 & 1977 & 1978 & 1979 \\
\hline Household Data: & & & & \\
\hline \% Of inspected houses which are infested: & 6.6 & 3.6 & 2.4 & 2.5 \\
\% Homes demolished in prior year: & 1.3 & 6.5 & 5.2 & 5.7 \\
\% Inspected houses which are sprayed: & 18.3 & 11.3 & 9.8 & 9.8 \\
\% Total houses not inspected: & 11.4 & 8.3 & 6.9 & 6.6 \\
Mean household size: & 4.02 & 3.55 & 3.48 & 3.50 \\
\% Growth (loss) of houses from prior period: & -6.6 & -1.5 & -.05 & -1.4 \\
\hline Triatomine Data: & & & & \\
\hline \% Localities with house-infestation: & 55.0 & 39.6 & 33.5 & 30.8 \\
\% Localities with following predominant & & & & \\
house-infesting vectors: & & & & \\
T. infestans & 26.0 & 18.6 & 10.9 & 6.1 \\
T. sordida & 48.0 & 38.9 & 48.7 & 48.1 \\
P. megistus & 26.0 & 42.2 & 36.6 & 41.1 \\
\% Localities with multiple house vectors: & 19.8 & 12.5 & 8.7 & 7.0 \\
Of the above, the second house vector is: & & & & \\
T. infestans & 40.2 & 57.0 & 60.3 & 61.3 \\
T. sordida & 38.0 & 35.0 & 27.9 & 29.0 \\
P. megistus & 14.1 & 5.2 & 11.8 & 9.7 \\
\hline \hline
\end{tabular}

TABLE 3. Regression Models for Household Triatomine Infestation Stratified by Mean Household Size: Triangulo Mineiro, 1979

\begin{tabular}{|c|c|c|c|c|}
\hline $\begin{array}{l}\text { Localities with a Mean of } 3 \text { or More Persons/House } \\
(n=283, \text { R-square }=.29)\end{array}$ & & s.e. & $\bar{T}$ & p< \\
\hline Intercept & -.001 & .005 & & \\
\hline $\begin{array}{l}\text { Presence of: } \\
T . \text { infestans } \\
T . \text { sordida } \\
\text { P. megistus }\end{array}$ & $\begin{array}{l}.023 \\
.012 \\
.039\end{array}$ & $\begin{array}{l}.017 \\
.009 \\
.007\end{array}$ & $\begin{array}{l}1.33 \\
1.33 \\
5.03\end{array}$ & $\begin{array}{r}.18 \mathrm{NS} \\
.18 \mathrm{NS} \\
.0001\end{array}$ \\
\hline $\begin{array}{l}\text { \% Demolished Houses } \\
\text { \% New Houses }\end{array}$ & $\begin{array}{l}.018 \\
.037\end{array}$ & $\begin{array}{l}.019 \\
.029\end{array}$ & $\begin{array}{l}.93 \\
1.3\end{array}$ & $\begin{array}{l}.35 \mathrm{NS} \\
.19 \mathrm{NS}\end{array}$ \\
\hline Ratio Infested outbuildings/all houses & .40 & .055 & 7.28 & .0001 \\
\hline \multicolumn{5}{|l|}{ Localitles with Less than 3 Persons/House $(n=159, R=.54)$} \\
\hline Intercept & -.015 & .005 & & \\
\hline $\begin{array}{l}\text { Presence of: } \\
\text { T. infestans } \\
\text { T. sordida } \\
\text { P. megistus }\end{array}$ & $\begin{array}{l}.127 \\
.036 \\
.044\end{array}$ & $\begin{array}{l}.026 \\
.010 \\
.011\end{array}$ & $\begin{array}{l}4.75 \\
3.57 \\
3.79\end{array}$ & $\begin{array}{l}.0001 \\
.0005 \\
.0002\end{array}$ \\
\hline $\begin{array}{l}\text { \% Demolished Houses } \\
\text { \% New Houses }\end{array}$ & $\begin{array}{r}.135 \\
.32\end{array}$ & $\begin{array}{l}.028 \\
.039\end{array}$ & $\begin{array}{l}4.74 \\
8.07\end{array}$ & $\begin{array}{l}.0001 \\
.0001\end{array}$ \\
\hline Ratio Infested outbuildings/all houses & .13 & .050 & -1.52 & $.131 \mathrm{NS}$ \\
\hline
\end{tabular}


between net increases in new housing and lower levels of house infestation. Migrant-tolocal inhabitant ratios were not available in 1979, but the net growth (loss) of houses per locality may serve as a proxy for population shifts in 1979, again principally occurring in urban locations.

However, in 1979 model interaction effects are again noted for house infestation, this time between vector species, demolition effects, and localities where average household size is three persons or more per dwelling, versus localities with a smaller average household size. Again, separate models are required to interpret house infestation in these two strata.

In the 283 localities (12 urban and 271 rural) which had an average household size of three or more persons in $1979, T$. infestans and $T$. sordida no longer enter the house infestation model, nor do the rates of house demolition or new construction (Table 3 ). In fact, two variables, the presence of $P$. megistus and the ratio of infested outbuildings to houses, explain $30 \%$ of the variance in house infestation in these high household-size locations. Also most of the urban locations are included in this strata.

In contrast, the 159 localities (1 urban and 158 rural) where the average household size was less than three persons, all three major vectors were still significant, independent covariates of infestation. $T$. infestans still contributes three times the level of infestation in comparison to the other two triatomine species. However, in these low-household size localities, house demolition now contributes to infestation rates to a slightly greater degree than the presence of $T$. infestans. It is in these localities that the greater the ratio of new-toexisting housing, the greater the level of house infestation. This factor's independent contribution to house infestation level equals that of the combined effects of all three vector species and house demolition put together. The final 1979 model for lowhousehold size localities, including the three vector species, house demolition, and new housing explained some $54.0 \%$ of the variance in house infestation.

\section{DISCUSSION}

At the onset of the control program, $T$. infestans infested houses at roughly twice the rate of the other two vectors. Its predominant role in malaria-program areas may reflect a preferred ecological niche, a natural route from its territory to the south, and/or a greater prevalence of low-quality (e.g. mud/stick) housing in which to dwell. Its dominance in house infestation agrees with community-level observations where prolific $T$. infestans colonies discourage competition from other species (Marsden et al., 1982). Overall, however, in 1976 T. infestans and P. megistus were found in equal numbers of localities, or $26.0 \%$ of the sample respectively.

House demolition also occurred at a greater rate in malarial areas, and it was only here that it became a significant covariate of infestation in remaining houses. At baseline, the role of house demolition was equivalent to that of having a second vector species operating in the locality. A greater dispersal of $T$. infestans due to demolition in malariaprogram localities seems unlikely as an interaction term for these two variables was not significant.

Researchers suggest DDT use in antimalarial program had little or no direct effect on triatomines (Marsden, 1981). However, the absence of outbuilding infestation effect on house infestation in malaria areas would be consistent with anecdotal information that anti-malarial spraying caused greater dispersal of house-loving triatomines away from human habitats. In any event, the anti-malaria program was successful, and it ceased in most locations by the next decade.

The available 1976 indicator of migration by location of birth may not adequately reflect recent, localized population changes. In the same vein, averaged household size varied little by rural-urban, or malarial/non-malarial areas in the baseline period. Finally, net gain in new housing rarely occurred, thus limiting sample power to detect an effect of this variable on house infestation. None of these variables reached significance when the type of vector was already included in the 1976 models. 
By 1979 , the triatomine infestion differences between malaria and non-malaria program areas diminish, whereas locations with small average household size appear to lose both housing and population, including one urban setting. While relatively greater ratios of new-to-existing housing appear in such communities, versus those with larger households, total available housing is still slightly decreasing, indicating construction is not even replacing the former housing supplies.

The independent roles of both demolition and new-to-old housing in these settings may be due to one or more behaviors. Triatomines may have been transported to new houses through re-used construction materials or in residents' belongings (Miles, 1976). More simply, demolition of houses may drive triatomines, especially $T$. infestans, to seek the human blood sources in both new and existing dwellings.

Areas with higher person per household densities may not have experienced an outflow of their population. Their rates of house demolition and construction are about one-tenth that of less-crowded household areas, consistent with stable or slow growing population, and a relatively constant supply of housing. For example, Marsden (1981) describes a town in Goiás state in which the absolute number of infested houses falls between 1975 and 1979 in the municipal seat, while the relative percentage of infested homes remained unchanged (or about $24.0 \%$ ). A new highway brought added population growth, but produced little change in the total supply of housing. The average household size, on the other hand, grew from 5.5 to 6.7 persons.

In predominantly $P$. megistus infested areas of Brazil, Piesman and colleagues (1983) found $70.0 \%$ of a community's houses with 4 or more persons to be densely infested, in comparison to only $20.0 \%$ of houses with fewer residents. As $P$. megistus is a slower and more easily disrupted feeder than $T$. infestans, higher human densities would favor this vector (Schofield, 1985). In the Triangulo region, the more free-ranging $P$. megistus may have survived in less well-sprayed annexes to re-infest these houses (Dias, 1979). High rates of outbuilding infestation, and the latter's significant influence on house infestation in more crowded household areas are consistent with this interpretation.

\section{CONCLUSIONS}

This study explored the roles of human migration, household size, construction and demolition of dwellings, when controlling for major insect vectors, in explaining initial levels of house infestation in a large region of Minas Gerais state. Of these, only crowding had specifically been addressed in the Chagas' disease literature. The second goal was to determine whether these factors continued to influence house infestation, once the control program was underway, given changes in the vector densities and distributions.

Researchers have long noted the portability of insect vectors in human belongings (Miles, 1976; Dias, 1985), and the role of migration in re-establishing other endemic diseases in non-endemic areas (Marques \& Pinheiro, 1979; Marques, 1982). Similar patterns have been suggested for Chagas' disease (Mott et al., 1990; Barrett, 1979; Zicker, 1989). However, data on localized population movement, or on household level changes are infeasible to monitor at the level of a national program.

In this study, the ratio of immigrant-tolocally born adults in the 1976 sample only approached significance in those areas in which house demolition occurred at a much slower pace, and where $T$. infestans was not as dominant a vector. The measure of migration available for 1976 may be too crude to detect major differences in infestation during the actual 1976 inspection visits. However, questions could be raised whether the relative role of human transport of triatomines in infesting dwellings increases when $T$. infestans no longer plays a major role, or when there is little disruption of triatomines' domestic habitat. Both aspects would be pertinent to the control program in fast-growing peri-urban locations, for example. 
The positive relation between house demolition and infestation has been broached, but never directly evaluated in the literature. In this sample, the effect of demolition appears to be centered in communities with high periodic loss of housing, and null or negative replacement by new construction. In the 1979 sample, demolition effects were also most notable in areas where $T$. infestans still played a major role in house infestation. In fact, it is difficult to determine whether demolition and $T$. infestans infestation are causally inter-related, or whether these communities were simply losing both population and housing at that time. In contrast, communities dominated by $P$. megistus exhibited lower rates of demolition, which in part may explain why this factor was not a significant covariate in the models for such communities. Colonies of $P$. megistus are often smaller and more freeranging in the household environs than those of $T$. infestans. Thus, the former's dispersal by demolition may simply make a lesser impact on neighboring houses, or alternatively may increase annex infestation instead.

The role of new construction has also not been addressed heretofore. Rates of new construction were fairly low in the 1976 sample, failed to result in any net gain in housing, and did not enter the 1976 models of house infestation. Three years later however, urban and some rural areas were experiencing greater rates of new home building. Again construction appears only to barely replace existing demolished homes, and its positive influence on house infestation would appear consistent with human transport of triatomines from old residences to the new.

Today T. infestans is well controlled in a majority of the regions sprayed by the program, where most communities exhibit less than $5 \%$ of households to be infested (Dias et al., 1985). The program now relies on local informants to report re-infestation in these communities, rather than on regularly scheduled inspections (Dias et al., 1985; Dias, 1986, 1988; WHO/SERWG, 1983). $T$. infestans is not totally eliminated however, and still occurred in outbuildings in the Triângulo region as late as 1985, and in houses in the northern part of the state (Dias et al., 1985).

Control of the more ecologically versatile $P$. megistus and $T$. sordida, particularly in outbuildings, has been less successful. This study confirms community-level observations (Dias, 1979; Marsden et al., 1982; Foratinni et al., 1971) where $P$. megistus emerges as the dominant house vector when $T$. infestans is eliminated, and the long-term infestation of outbuildings by $T$. sordida (Dias, 1979). Researchers have struggled to develop new mechanisms to retain the effectiveness of insecticides in the flimsy annex constructions (Dias, 1988; Tonn, 1980). Indeed, triatomines' ecologic versatility in shifting between domestic and sylvatic environments makes their long-term control especially problematic (Zeledon \& Rabinovich, 1981).

The relative contribution of outbuilding infestation to dwelling infestation, apart from that explained by the presence of specific vector species, has not been examined on a regional level. This study confirms the expected role of infested outbuildings as an independent covariate, especially where non$T$. infestans vectors begin to emerge. In one Triângulo region county, all three vectors occur in both rural and urban household annexes, during the period of 1978 to 1985 , even when house infestation is no longer reported. This is particularly true for storage barns and poultry coops, which pose a particular danger given the ready transport of farm products between domestic environs and the kitchen, and between rural and urban settings (Fleming-Moran, unpublished ms.). As part of the control programs' educational efforts, local inhabitants are urged not to transport firewood, or farm produce into the home.

Finally, this study presents the first regional level confirmation of the association between household crowding and the percentage of infested houses in a community. Once more, as $T$. infestans' role diminishes, human factors may play a greater part in determining household infestation. Over the three year study period, the regions' average household size declines, but shifts in population also occur. Areas with an average household size 
of three or more persons were those with $P$. megistus as a dominant species. They also exhibited low growth in available housing, where housing demolition continues, and includes most of the 1979 urban sample, as well as many rural locations.

Given Brazil's highly mobile population, an endemic disease surveillance and control system needs to account for the effects of significant, if localized, shifts in population. This implies use of proxy variables to highlight population change. Brazil's unique collection of community specific data on total housing, new construction, and demolition by semester allows the potential to target specific localities at risk of re-infestation, that is, those with rapid changes in local housing. Such data are obviously important in the control of Chagas' disease, but may be useful in yellow fever and malaria surveillance as well. Brazil's Sucam house enumeration system makes such monitoring feasible.

These data further suggest house infestation occurs under certain conditions, such as human crowding, and shifts in triatomine vectors. As of 1979, local population estimates are no longer kept by the control program. Recent computerization of program records could facilitate the recapture of demographic information to pinpoint areas resistant to triatomine control, or those at high risk of re-infestation. During the shift from a "vertical" delivery mode of the control program to one which includes greater administration at the local level (Dias, 1986; 1988), local informants may also need to provide timely information on fluxes in community population, as well as reporting triatomine infestation. Testing these evaluative approaches will be important in providing needed data on long-term triatomine control, especially in expanding peri-urban areas and rural development projects.

\section{ACKNOWLEDGEMENTS}

This project was supported by a grant from the National Science Foundation (NSF\#8809340), and by funding from the Indiana University's International Development
Institute and Inter-Campus Research Fund. The author wishes to thank Dr. João Carlos Pinto Dias, former director of the Chagas' Disease Control Porgram, of the Brazilian Ministry of Health, and of his staff in Brasilia, and of the program in the state of Minas Gerais, who so greatly assisted in the identification and collection of the data used in this study. In addition, Drs. M. Camargo and J. Litvoc, of the University of São Paulo, generously shared data from the National Chagas' Disease Serological Survey. The author also wishes to thank Drs. P. D. Marsden, M. T. Garcia-Zapata, V. Macedo, D. A. Mello, and M. G. Pereira, of the University of Brasilia, who willingly gave of their time and expertise. At Indiana University, special thanks are given to Drs. J. Hopkins, D. Freund, and E. P. Morgan who reviewed an earlier version of this manuscript, and to K. Pickett and L. Roholt, who helped prepare the data for analysis.

\section{RESUMO}

\section{FLEMING-MORAN, M. O Sucesso Inicial do Programa de Controle da Doença de Chagas: Fatores Associados com a Infestação por Triatomíneos. Cad. Saúde} Públ., Rio de Janeiro, 8 (4): 391-403, out/dez, 1992.

Embora tenha sido controlado o principal vetor da doença de Chagas - o Triatoma infestans - em muitas áreas endêmicas do Brasil, os dados do início do programa de controle referentes ao Triângulo Mineiro (1976-79) sugerem a ocorrência de reinfestação por triatomíneos sob determinadas condições favoráveis. A autora compara as taxas de infestação domiciliar em 500 comunidades da região do Triângulo Mineiro para os anos de 1976 e 1979 , utilizando modelos de regressão linear. Controlando para os três principais vetores triatomíneos, são variáveis independentes da infestação domiciliar nessas comunidades o amontoamento intra-domiciliar, a demolição e construção de habitações e as construçōes anexas infestadas. Embora vários fatores 
domiciliares tenham sido sugeridos como correlatos da infestação, o programa de controle se concentra nos índices comunitários de infestação, enquanto as comparações intracomunitárias e regionais, até agora, têm-se mostrado inviáveis. Os dados computadorizados estão-se tornando disponíveis na identificação de comunidades sob alto risco de infestação, assim como, na definição de estratégias e atividades para os programas.

Palavras-Chave: Doença de Chagas; Controle; Triatoma sp.; Brasil

\section{REFERÊNCIAS BIBLIOGRÁFICAS}

BARRETT, T. V., 1979. An outbreak of acute Chagas' disease in the São Francisco valley region of Bahia, Brazil: triatomine vectors and animal reservoirs of $T$. cruzi. Transactions of the Royal Society of Tropical Medicine and Hygiene, 73: 703-709.

BENTHAM, G., 1988. Migration and Morbidity: Implications for Geographical Studies of Disease. Social Science and Medicine, 26: 49-54.

BRENER, Z., 1982. Recent developments in the field of Chagas' Disease. Bulletin of the World Health Organization, 60: 463-73.

CAMARGO, M. E.; SILVA, G. R.; CASTILHO, E. A. \& SILVEIRA, A. C., 1984. Inquérito sorológico da prevalência da infecção chagásica no Brasil. 1975-80. Revista do Instituto de Medicina Tropical de São Paulo, 26: 192-204.

DE RAAT, P., 1976. Improvement of rural housing as a means of control of Chagas' disease. In: New Approaches in American Trypanosomiasis Research. Scientific Publication No. 18, pp. 323325, Washington, D.C: Pan American Health Organization.

DIAS, J. C. P., 1979. Epidemiological aspects of Chagas' disease in the west of Minas Gerais, Brazil. Environmental, ecologic, and human aspects studied by the Bambui Center (Fiocruz) during the period 1943-1979. Anais do Congresso Internacional sobre Doença de Chagas, pp. H1-H6, Rio de Janeiro: Fiocruz.

1985. Aspectos sócio-culturais e econômicos na expansão e no controle de Chagas. Annales de la Société Belge de Médecine Tropicale, 65 (supplement 1): 119-26.

1986. Integração das ações de controle das endemias com a rede básica de saúde: Doença de Chagas. Revista Brasileira de Malariologia e Doenças Tropicais, 38: 77-85.
1988. Innovation in Chagas' Disease Control: The Perspective from the Government Control Programmes. Tropical Disease Research Programme, Geneve: WHO. (Mimeo.)

DIAS, J. C. P.; LOYOLA, C. C. P. \& BRENER, S., 1985. Doença de Chagas em Minas Gerais: Situação atual e perspectivas. Revista Brasileira de Malariologia e Doenças Tropicais, 37: 7-28.

DIAS, J. C. P. \& DIAS, R. B., 1982. Housing and the control of the vectors of human Chagas' disease in the state of Minas Gerais, Brazil. Bulletin of the Panamerican Health Organization, 16: 121-29.

1981. Participação da comunidade em programas de controle da Doença de Chagas. In: Situação e Perspectivas Descritivas das Doenças Infecciosas e Parasitárias, pp. 293-312, Brasília: Editora Universidade da Brasilia.

FORATINI, O. P.; FERREIRA, O. \& SILVA, A., 1971. Aspectos ecológicos da tripanossomíase americana. II. Distribuição e dispersão local de triatomíneos em ecótopos naturais e artificiais. Revista de Saúde Pública, 5: 163-191.

GOLDSMITH, R. S.; ZARATE, R. J.; ZARATE, L. G.; KAGAN, I. \& JACOBSEN, L. B., 1985. Clinical and epidemiological studies of Chagas' disease in rural communities in Oaxaca state, Mexico: a seven year followup. Bulletin of the Panamerican Health Organization, 19: 120137.

GRANT, I. H.; GOLD, J. W. \& WITTNER, M., 1989. Transfusion associated acute Chagas' disease acquired in the United States. Annals of Internal Medicine, 111: 849-851.

HADDOCK, K. C., 1979. Disease and Development in the Tropics: A review of Chagas' Disease. Social Science and Medicine, 13D: 53-60.

HOFF, R. C. W.; TODD, J. H.; MAGUIRE, J.; PIESMAN, K. E. \& MOTT, E., 1985. Serological surveillance of Chagas' disease. Annales de la Société Belge de Médecine Tropicale, 65 (supplement 1): 187-196.

JULIEN-LAFERRIERE, D.; ESTERRE, P.; FRENAY, C. \& DEDET, J. P., 1989. Epizoology of Chagas' disease near a forest settlement in French Guiana. Transactions of the Royal Society of Tropical Medicine and Hygiene, 83: 202-207.

KIRCHHOFF, L. V.; GAM, A. A. \& GILLIAM, F. G., 1987. American Trypanosomiasis (Chagas' Disease) in Central American immigrants. American Journal of Medicine, 82: 915-920.

KLEINBAUM, D.; KUPPER, L. \& MORGANSTERN, H., 1982. Epidemiologic Research. Belmont CA: Lifetime Learning Publications. 
LITVOC, J., 1979. Movimentos migratórios e Doença de Chagas. Anais do Congresso Internacional sobre Doença de Chagas. Rio de Janeiro: Fiocruz.

MARQUES, A. C. \& PINHEIRO, E. A., 1979. Migrações internas e as grandes endemias. Revista Brasileira de Malariologia e Doenças Tropicais, 31: 158.

MARQUES, A. C., 1982. Fluxos de casos de malária no Brasil em 1980. Revista Brasileira de Malariologia e Doenças Tropicais, 34: 1-31.

MARSDEN, P. D., 1981. The control of Chagas' disease in Mambaí, Brazil: The initial phases. Infection and Control, 2: 466-470.

1984. Selective primary health care: strategies for control of disease in the developing world: Chagas'disease. Reviews of Infectious Diseases, 6: 855.

MARSDEN, P. D.; VIRGENS, D.; MAGALHÃES, I.; TAVARES-NETO, J.; FERREIRA, R.; COSTA, C. H.; CASTRO, C. N.; MACEDO, V. \& PRATA, A., 1982. Ecologia doméstica do Triatoma infestans em Mambai, Goiás, Brasil. Revista do Instituto de Medicina Tropical de São Paulo, 24: 364-373.

MAURICE, J. \& PEARCE, A. M. (Eds.), 1987. Tropical Disease Research: A Global Partnership Eighth Programme Report: The First Ten Years with highlights of the 1985-86 biennium. pp. 8990. Geneva: World Health Organization; Special Program for Research and Training in Tropical Diseases.

MILES, M. A., 1976. Human Behavior and the propagation of Chagas' disease. Transactions of the Royal Society of Tropical Medicine and Hygiene, 70: 521-22.

MOTA, E. A.; GUIMARÃES, A. C.; SANTANA, O. O.; SHERLOCK, I. A.; HOFF, R. \& WELLER, T., 1990. A nine-year prospective study of Chagas' disease in a defined rural population in northeast Brazil. American Journal of Tropical Medicine and Hygiene, 42: 429-440.

MOTT, K. E.; MUNIZ, T. M.; LEHMAN, J. S.; HOFF, R.; MORROW, R. H.; OLIVEIRA, T. S.; SHERLOCK, I. A. \& DRAPPER, C. C., 1978. House construction, triatomine distribution, and household distribution of seroreactivity to $T$. cruzi in a rural community in northeast Brazil. American Journal of Tropical Medicine and Hygiene, 27: 1116-1122.

MOTT, K. E.; DESJEAUX, P.; MONCAYO, A.; RANQUE, P. \& DeRAADT, P., 1990. Parasitic diseases and urban development. Bulletin of the World Health Organization, 68: 691-98.
MS (Ministério da Saúde); SUCAM (Superintendência de Controle da Malária) \& WORLD BANK, 1987. Projeto de Controle de Doenças Endêmicas no Nordeste. Banco Internacional de Reconstrução e Desenvolvimento, pp. 12-27.

OFICINA SANITÁRIA PANAMERICANA, 1985. Reseñas: Situación de la enfermedad de Chagas en las Americas. Boletin de la Oficina Sanitária Panamericana, 97: 159-65.

PEREIRA, M. G., 1984. Characteristics of urban mortality from Chagas" disease in Brazil's Federal District. Bulletin of the Panamerican Health Organization, 18: 1-9.

PIESMAN, J.; SHERLOCK, I. A.; MOTA, E.; TODD, C. W.; HOFF, R. \& WELLER, T. H., 1985. Association between triatomine density and incidence of Trypanosoma cruzi infection during a nine-year study in Castro Alves, Bahia, Brazil. American Journal of Tropical Medicine and Hygiene, 34: 866-69.

PIESMAN, J.; SHERLOCK, I. A. \& CHRISTENSEN, H., 1983. Host availability limits population density of Panstrongylus megistus. American Journal of Tropical Medicine and Hygiene, 32: 1445-50.

SCHOFIELD, C. J., 1980. Nutritional status of domestic populations of Triatoma infestans. Transactions of the Royal Society of Tropical Medicine and Hygiene, 74: 770-78.

1985. Control of Chagas' Disease vectors. British Medical Bulletin, 41: 187-94.

SCHOFIELD, C. J. \& MARSDEN, P. D., 1982. The effect of wall plaster on a domestic population of Triatoma infestans. Bulletin of the Panamerican Health Organization, 16: 356-60.

SILVEIRA, A. C., 1985. O programa de controle de Chagas no Brasil. Annales de la Société Belge de Médecine Tropicale, 65 (supplement 1): 137148.

TONN, R., 1980. Chagas' disease control programmes: Evaluation and perspectives. Tropical Disease Research Program. Document no. TDR/CHA-SER/WSP/80.6. Mimeograph pp.2-4.

VICHI, F. L.; COSTA, J. C.; NETO, M. M. \& ROMERO, L. C., 1980. Declínio na moléstia de Chagas em Riberão Preto (SP): Estudo Epidemiológico. Arquivos Brasileiros de Cardiologia, 34: 347-349.

WHO (World Health Organization) \& SERWG (Social and Economic Research Working Group), 1983. Community Participation in Tropical Disease Control: Social and Economic Re. search Issues. Geneve: TDR/SER-SWG/C.P. 8 . 3.3. 
ZELEDON, R. \& RABINOVICH, J. E., 1981. Chagas' Disease: an ecological appraisal with special emphasis on its insect vectors. Annual Review of Entomology, 26: 101-133.

ZELEDON, R. \& VARGAS, L. G., 1984. The role of dirt floors and of firewood in rural dwellings in the epidemiology of Chagas' disease in Costa Rica. American Journal of Tropical Medicine and Hygiene, 33: 232-235.
ZICKER, F., 1989. Seroprevalence of Trypanosoma cruzi infection among unskilled urban workers in Central Brazil. Transactions of the Royal Society of Tropical Medicine and Hygiene, 83: 511-513. 